\title{
Alpha fetoprotein DNA prime and adenovirus boost immunization of two hepatocellular cancer patients
}

\author{
Lisa H Butterfield ${ }^{1 *}$, James S Economou ${ }^{2}$, T Clark Gamblin ${ }^{3}$ and David A Geller ${ }^{4}$
}

\begin{abstract}
Background: Alpha fetoprotein (AFP) is an oncofetal antigen over-expressed by many hepatocellular cancers (HCC). We previously demonstrated that HLA-A2-restricted epitopes derived from AFP are immunogenic in vitro and in vivo despite high circulating levels of this oncofetal antigen. In order to test a more broadly applicable, HLA-unrestricted, inexpensive, cell-free vaccine platform capable of activating tumor antigen-specific $\mathrm{CD}^{+}$and $\mathrm{CD}^{+} \mathrm{T}$ cells, we tested full length AFP in a plasmid DNA construct in combination with an AFP-expressing replication-deficient adenovirus (AdV) in a prime-boost vaccine strategy.
\end{abstract}

Methods: HCC patients who had an $\mathrm{AFP}^{+}$tumor and previous treatment for HCC were screened and two patients received vaccination with three plasmid DNA injections followed by a single AdV injection, all delivered intramuscularly (i.m.).

Results: The vaccine was well tolerated and safe. Both patients showed immunologic evidence of immunization. The first patient had a weak AFP-specific T cell response, a strong AdV-specific cellular response and recurred with an AFP-expressing HCC at nine months. The second patient developed a strong AFP-specific CD8 ${ }^{+}$and $C D 4^{+}$ cellular response and an AdV neutralizing antibody response, and recurred at 18 months without an increase in serum AFP.

Conclusions: The AFP DNA prime-AdV boost vaccine was safe and immunogenic. Circulating anti-AdV neutralizing antibodies at baseline did not prohibit the development of AFP-specific cellular immunity. The patient who developed $\mathrm{CD}^{+}$and $\mathrm{CD} 4^{+}$AFP-specific T cell immunity had more favorable progression-free survival. The observations with these two patients support development of this vaccine strategy in a larger clinical trial.

Trial registration: ClinicalTrials.gov: NCT00093548

Keywords: Alpha Fetoprotein, Hepatocellular cancer, Cancer vaccine, Prime-boost

\section{Introduction}

Hepatocellular carcinoma (HCC) is one of the most common cancers globally, with an incidence of over 600,000 new cases per year. While the majority of cases are primarily in sub-Saharan Africa and Eastern Asia, it is also the fastest growing cause of cancer-related death of males in the United States (US) [1]. Within the past 30 years, the incidence and mortality rates for HCC have

\footnotetext{
* Correspondence: butterfieldl@upmc.edu

'University of Pittsburgh Cancer Institute, Departments of Medicine, Surgery, and Immunology, University of Pittsburgh, 5117 Centre Avenue, PA, Pittsburgh 15213, USA

Full list of author information is available at the end of the article
}

tripled in the US [2]. The primary risk factors for developing $\mathrm{HCC}$ are cirrhosis (independent of its etiology), and chronic infection with hepatitis B virus (HBV) or hepatitis $\mathrm{C}$ virus (HCV). In the US, it is estimated that $47 \%$ of HCC cases are attributed to chronic HCV infection, with an additional $15 \%$ to HBV [3]. HBV infection is endemic in South-East Asia and Sub-Saharan Africa, and there is a global pandemic of $\mathrm{HCV}$ infection. Chronic $\mathrm{HCV}$ infection likely accounts for the increased incidence of HCC in several Western countries, where incidence has risen to 5-20/100,000 (Spain, Italy and Greece), and to 13.6/100,000 (the UK, Canada and the US) [1]. Diabetes and obesity are also risk factors, hence HCC is expected to 
become a progressively greater health problem in the future [4].

Once diagnosed, HCC has a dismal prognosis. Small, localized tumors are potentially curable with surgery (resection and liver transplantation), however, less than $20 \%$ of HCC patients are eligible for these procedures because most patients have advanced disease at diagnosis or have liver dysfunction limiting aggressive treatment [5]. Localregional therapy is largely palliative and includes cryoablation, radiofrequency ablation (RFA), microwave ablation, ethanol injection and transarterial embolization (TAE). TAE relies largely on obstruction of the hepatic artery branches to the tumor in order to induce subsequent tumor necrosis. HCC is resistant to chemotherapy and other systemic treatment approaches. The multi-targeted tyrosine kinase inhibitor, sorafenib, which improves survival by 2.3-2.8 months, is the only systemic agent found to increase survival in patients with advanced HCC and is currently the standard of care [6,7]. A number of other molecularly targeted approaches, all of which target signaling pathways activated in HCC, are under investigation [7]. However, the drug-metabolizing properties of the liver, in addition to elevated levels of multi-drug resistance proteins expressed by HCC cells, likely contributes to the limited efficacy of chemotherapeutics and small molecule drugs in the treatment of HCC [8]. Overall, however, the median survival for patients with advanced stage, unresectable HCC is less than one year [5].

Immunotherapy represents an attractive alternative to these traditional therapies based on the sensitivity and specificity of the immune system. While HCC is not generally considered an "immunogenic" tumor, patients whose tumors contain lymphocytic infiltrates show longer survival and lower risk of recurrence [9]. AFP is an oncofetal antigen and the most abundant serum protein in the fetus [10]. At birth, levels drop to $30-100 \mathrm{mg} / \mathrm{ml}$ and the adult level of AFP is $1-3 \mathrm{ng} / \mathrm{ml}$. Forty to $80 \%$ of HCC express AFP, and serum assays play an important role in diagnosis and monitoring responses to treatment. Levels $>20 \mathrm{ng} / \mathrm{ml}$ are generally considered abnormal, and $>200 \mathrm{ng} / \mathrm{ml}$ are specific for HCC in patients with cirrhosis [5]. The normal biologic function of AFP is still unknown. It has been hypothesized to play a role in the transport of serum components, including fatty acids, steroids, and heavy metals [11]. There have also been reports of an immune suppressive role of AFP [12].

Studies in HCC patients indicate that circulating AFPspecific $\mathrm{T}$ cells can be activated ex vivo and can recognize tumor despite high circulating serum levels of this antigen [13-17]. Polyclonal AFP-specific T cells can also be detected in the livers of chronically infected $\mathrm{HCV}^{+}$and $\mathrm{HCC}$ patients [18]. Furthermore, elimination of Treg can unmask AFP-specific T cells in HCC patients [19]. Importantly, AFP expression in HCC tumor cells is associated with increased tumor proliferation, apoptosis resistance, and it is expressed in $\mathrm{CD} 45^{-} \mathrm{CD} 90^{+}$ putative $\mathrm{HCC}$ cancer stem cells, supporting its targeting as a biologically relevant tumor-associated antigen [20].

Two clinical trials have been conducted testing MHC class I-restricted peptides derived from AFP either emulsified in Montanide [14] or pulsed onto autologous DC [21]. The immunological responses detected demonstrated that AFP peptide epitopes were immunogenic in vivo and were able to stimulate IFN $\gamma$-producing antigen-specific $\mathrm{CD}^{+} \mathrm{T}$ cells in patients with very high serum levels of AFP. In the second trial, 10 patients (with stage III-IV disease) were immunized and 6 showed AFP-specific T cell increases by MHC tetramer, and 6 had increased frequency of IFN- $\gamma$ producing, AFP-specific T cells by ELISPOT [15,21], again demonstrating immunological activity of the AFP-based vaccine. Two AFP peptide/DC vaccinated patients experienced transient decreases in serum AFP.

In order to provide cognate $\mathrm{CD} 4^{+} \mathrm{T}$ cell help to support CTL activity, in addition to direct activation of multiple epitope-specific $\mathrm{CD}^{+} \mathrm{T}$ cells [22,23], and to eliminate HLA-restriction requirements, we previously tested a full length AFP strategy in a murine model. Murine AFPencoding plasmid DNA injection "priming" followed by a "boost" with murine AFP-encoding AdV was performed in an HCC tumor model [13]. This strategy was immunogenic, and had strong antitumor activity. Based on this model, and other promising data on heterologous primeboost strategies [24], we cloned human AFP into a simple plasmid backbone (pVAX1), and created a human AFPexpressing AdV [25]. These AFP constructs, in addition to a plasmid encoding human GM-CSF, were prepared to good manufacturing practice (GMP) grade (NCI RAID Project \#176), and tested in two patients with previously treated AFP-expressing HCC. Here we present the clinical and immunologic outcomes of these patients receiving the AFP DNA-prime-AdV boost vaccine.

\section{Materials and methods \\ Patients}

Enrollment inclusion criteria included patients 18 years and older, with a history of $\mathrm{AFP}^{+} \mathrm{HCC}$, stage II-IVa, after locoregional therapy (resection, RFA, cryoablation, ethanol injection, chemoembolization and radioembolization), with Karnofsky performance status $\geq 70 \%$, and conserved liver function (Child-Pugh class A or B). Exclusion criteria included acute infection (other than HBV or HCV), HIV infection, organ allografts, or chemotherapy or steroid therapy in the last 30 days.

The first patients screened were excluded for: lack of HLA-A2 positivity (the first screened patient; a criterion later eliminated), very high levels of circulating anti-AdV neutralizing antibodies (patients 2 and 3), early progression (patients 2 and 4), or other non-HCC-related conditions. 
Patient 7, the first vaccinated, was male, 80 years, Caucasian, $\mathrm{HBV}^{-} / \mathrm{HCV}^{-}$, with stage II $\mathrm{HCC}$ and was vaccinated between 11/2010-2/2011. Patient 8 , the second vaccinated, was female, 81 years, Caucasian, was stage II HCC with cryptogenic cirrhosis. She was vaccinated between 12/2010-3/2011. Further clinical details are presented in the Results.

\section{Vaccines}

The vials of plasmid DNA (pAFP and pGM-CSF) and the AdV (AdVhAFP) were prepared to GMP by the NCI BRB RAID program (Stephen Creekmore, Chief), and underwent stability testing at months 3, 6, 12 and then annually at the SAIC Frederick, Inc. Vials were stored at $-80^{\circ} \mathrm{C}$ in a temperature controlled and monitored freezer in the University of Pittsburgh Immunologic Monitoring and Cellular Products Laboratory (IMCPL). For each vaccination, vials were transported to the clinic on wet ice, thawed, and drawn into syringes for intramuscular deltoid injections. Before vaccination, patients received $650 \mathrm{mg}$ acetaminophen and $50 \mathrm{mg}$ diphenhydramine. For each of the three monthly plasmid injections, $2.5 \mathrm{mg}$ of pAFP and $2.5 \mathrm{mg}$ of pGM-CSF were mixed together in the syringes before injection. For the dose of $10^{9}$ pfu of AdVhAFP, the virus was diluted in sterile saline in the IMCPL before preparing the syringe for injection.

\section{Clinical assessments}

All patients were presented at a weekly multi-disciplinary Liver Tumor Board at the University of Pittsburgh Medical Center and deemed eligible for the clinical trial. All patients consented to participate in the AFP vaccine trial which was IRB-approved by the University of Pittsburgh Medical Center. Patients underwent routine history and physical examination, laboratory work, and serum AFP level. Radiologic evaluation consisted of triphasic abdominal CT scan or liver MRI with contrast. Serial imaging was done every 3-4 months after treatment. HCC recurrence was documented by rise in AFP level and CT/MRI imaging showing a recurrent tumor meeting $\mathrm{HCC}$ criteria.

\section{Blood processing}

Blood samples were transported to the IMCPL on the date of draw immediately were processed according to laboratory SOPs. Serum was isolated from red top vacutainers (BD) by centrifugation after clot formation and frozen in aliquots at $-80^{\circ} \mathrm{C}$. After removal of whole blood for fresh flow cytometry, PBMC were isolated from the green top vacutainer tubes (BD) containing heparin via Ficoll gradients, and PBMC were cryopreserved in aliquots and stored in liquid nitrogen vapor. Viability was $92-98 \%$ upon thaw.

\section{Immunologic monitoring}

To determine the immune status of the patients and the effects of vaccination, peripheral blood was tested as follows in the IMCPL. All procedures followed SOPs and included healthy donor (HD) controls.

\section{Adenovirus ELISA}

F16 Maxisorp Nunc Immuno plates were blocked with 3\% BSA/PBS, then coated with AdVLacZ at $4 \cdot 10^{8} \mathrm{pfu} / \mathrm{ml}$ for 18-24 hours at $4^{\circ} \mathrm{C}$. Sera were thawed, serially diluted, and plated in duplicate. Plates were incubated for 2 hours at RT, washed 4 times, developed with rabbit anti-goat IgG-peroxidase, and read on a Dynex MRX plate reader. Negative control was HD serum with known low antiAdV antibody levels, the positive control was HD serum with known high levels of anti-AdV antibodies, and the standard was goat anti-human AdV antibody.

\section{Adenovirus neutralizing antibody flow cytometry}

Anti-AdV neutralizing antibodies were measured using serial dilutions of serum (1:4 to 1:512) cultured with an indicator cell line, A549 (ATCC), followed by transduction with an AdV-encoding enhanced Green Flourescent Protein (AdVeGFP), as described [26]. The cells were tested for the MFI of eGFP by flow cytometry. Controls included no AdVeGFP (negative) and no serum (positive).

\section{IFNץ ELISPOT}

The IFNY ELISPOT assay to detect AFP and AdVspecific $\mathrm{T}$ cell responses was standardized with PBMC from three HD. Responder $\mathrm{T}$ cell subsets were purified before plating $\left(\mathrm{CD}^{+}, \mathrm{CD}^{+}\right.$, Miltenyi Biotec $)$. There were no detectable baseline AFP-specific $\mathrm{CD}^{+}$or $\mathrm{CD}_{4}^{+}$ T cells, and 1 of $3 \mathrm{HD}$ had detectable AdV-specific $\mathrm{CD}^{+}$ T cells, while 2 of 3 HD had AdV-specific CD $4^{+} \mathrm{T}$ cells. Backgrounds were 0 , and PMA/ionomycin positive controls were $>1,000$ spots $/ 10^{5} \mathrm{CD}^{+}$or $\mathrm{CD}^{+}{ }^{+} \mathrm{T}$ cells.

Multi-screen HA plates (Millipore, MAHAS4510) were coated with 4-10 ug/mL of monoclonal capture $\mathrm{Ab}$ anti-human IFNy (1-D1K, MabTech), in PBS overnight at $4^{\circ} \mathrm{C}$. After blocking the plates with RPMI/10\% $\mathrm{AB}\left(1 \mathrm{~h}, 4^{\circ} \mathrm{C}\right), \mathrm{CD}^{+}$or $\mathrm{CD}^{+} \mathrm{T}$ cells were plated at $10^{5}$ cells/well in duplicate or triplicate wells. Autologous DC $\left(0.5-1 \times 10^{5}\right.$ well) were pulsed with different peptides $\left(\mathrm{AFP}_{158}, \mathrm{AFP}_{137}, \mathrm{AFP}_{325}, \mathrm{AFP}_{542}\right.$ (University of Pittsburgh Peptide Synthesis Facility)) loaded with protein (cord blood-derived AFP) or transduced with AdV, rinsed and plated. Control wells contained $\mathrm{T}$ cells (alone or with $1 \mathrm{ng} / \mathrm{mL} \mathrm{PMA}+1 \mu \mathrm{M}$ ionomycin), and $\mathrm{T}$ cells with unloaded DC. Cells were removed and captured cytokine was detected by corresponding biotinylated $\mathrm{mAb}$ (MabTech) at $2 \mu \mathrm{g} / \mathrm{mL}$ in PBS $/ 0.5 \%$ BSA. After washing, Avidin Peroxidase Complex (Vectastain Elite Kit) was added for $60 \mathrm{~min}$. After rinsing, peroxidase staining was 
performed with 3-amino-9-ethyl-carbazole (AEC, Sigma) and stopped by rinsing the plates under tap water. Spot numbers were automatically determined with ImmunoSpot imaging system from Cellular Technology, Ltd (Immunospot analyzer software version 5.0). To calculate the number of responding $\mathrm{T}$ cells, the mean number of spots detected with DC alone were subtracted from mean spot numbers induced by antigen-loaded DC. A "positive" response was considered $\geq 2 \mathrm{x}$ over baseline.

\section{Serum luminex}

Sera were thawed and simultaneously analyzed with the multiplex Luminex assay (30-plex, Invitrogen) per manufacturer's protocol in a BioRad reader (IMCPL). The following analytes were tested: GM-CSF, IFN $\gamma$, IP-10, MCP-1, TNF $\alpha$, IL-1 $\beta$, IL-2, IL-4, IL-5, IL-6, IL-8, and IL10, IL-15,IL-13, IL-17, IL-1R $\alpha$, MIP-1 $\beta$, IL-2r,IL-7 Exotaxin, MCP-1, MIG, MIP-1alpha and RANTES, in a kit pre-tested for any potential cross-reactivity by the manufacturer. Controls included the kit standard curve and Multiplex QC standards (R\&D Systems).

\section{Flow cytometry}

Whole blood was utilized for flow cytometry to determine the frequencies and phenotype of T cells, NK cells, NK/T cells, Treg and MDSC. Blood was processed and stained automatically per manufacturer's instructions on a TQ-PrepPlus2 (Beckman Coulter), and stained with CD3, CD16, CD56, CD69, CCR7, CD4, CD25, CD39, lineage, HLA-DR, CD14, CD11b, CD33 (Beckman Coulter) and/or intracellular FoxP3 (eBioscience), and analyzed on an FC500 flow cytometer using CXP v2.1 (Beckman Coulter) software.

\section{Results}

Patients

At baseline, patient 7 was free of active disease (CT scan), had normal AFP (1 ng/ml), Karnofsky performance status of $100 \%$, was Child-Pugh A, was HLA-A2 ${ }^{+}$ and had undetectable levels of anti-AdV neutralizing antibodies. At baseline, patient 8 was free active disease but positive for cirrhosis, had normal AFP (5 ng/ml), had Karnofsky performance status $80 \%$, was Child-Pugh $\mathrm{A}, \mathrm{HLA}-\mathrm{A} 2^{+}$, and had intermediate detectable levels of anti-AdV neutralizing antibodies which were in the acceptable range for trial enrollment.

\section{Clinical cases and outcomes}

Vaccinated patients had no clinically significant adverse events. Patient 7 is an 83 year old male who underwent laparoscopic partial right hepatic lobectomy for HCC on $1 / 18 / 07$. His background liver was normal, and pathology confirmed a $4.5 \mathrm{~cm}$ moderate to poorly differentiated HCC with negative margins. His pre-operative serum AFP level was 2,168 $\mathrm{ng} / \mathrm{ml}$, and it normalized to $<2 \mathrm{ng} / \mathrm{ml}$ post-resection. He developed a $2 \mathrm{~cm} \mathrm{HCC}$ recurrence in his liver and underwent laparoscopic radiofrequency ablation (RFA) on 2/19/10 which was 37 months after his initial HCC surgical resection. Liver biopsy at that time confirmed well-differentiated HCC just prior to the RFA. His AFP increased to $14 \mathrm{ng} / \mathrm{ml}$ at the time of recurrence, and normalized to $1 \mathrm{ng} / \mathrm{ml}$ postRFA. He received his first AFP vaccine injection on 11/ $17 / 10$ which was 46 months after his initial liver resection and 9 months after his RFA. He recurred on 8/11/ 11 when liver MRI showed a new enhancing liver tumor. This was 56 months after his initial liver resection, 19 months after his RFA, and 9 months after his first AFP vaccine injection. His AFP level was in the normal range at $5 \mathrm{ng} / \mathrm{ml}$ on $7 / 25 / 11$. He was started on Sorafenib therapy. His AFP remained in the normal range until 6/7/ 12 when his serum AFP level increased to $98 \mathrm{ng} / \mathrm{ml}$. It peaked at $508 \mathrm{ng} / \mathrm{ml}$ on $11 / 12 / 12$, and he was treated with

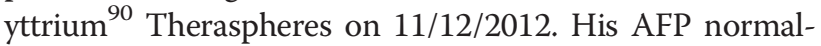
ized to $2.5 \mathrm{ng} / \mathrm{ml}$ on $5 / 7 / 13$, and remained normal at $1.9 \mathrm{ng} / \mathrm{ml}$ on $8 / 20 / 13$. He is still alive as of $10-10-13$.

Patient 8 is an 84 year old female who underwent laparoscopic partial right hepatic lobectomy for HCC on $11 / 6 / 09$. Her background liver was grossly cirrhotic, and surgical pathology of the resected tumor confirmed a $2 \mathrm{~cm}$ moderately differentiated $\mathrm{HCC}$ with negative margins. Her pre-operative serum AFP level was $61 \mathrm{ng} / \mathrm{ml}$, and it normalized to $4 \mathrm{ng} / \mathrm{ml}$ post-resection. She received her first AFP injection on 12/22/10. She had $\mathrm{HCC}$ recurrence in her liver documented by CT scan on 6/6/12 which was 31 months after her liver resection, and 18 months after the first AFP vaccine injection. Her AFP level remained in the normal range. She was treated with a brief course of Sorafenib, followed by observation. Her AFP increased to $13 \mathrm{ng} / \mathrm{ml}$ on $9 / 25 / 13$. She is still alive as of 10-10-13, which is 47 months from her resection, and 34 months after the first AFP vaccine injection.

\section{Cellular immune responses to AdV and AFP detected}

$\mathrm{CD}^{+}$and $\mathrm{CD}^{+}{ }^{+} \mathrm{T}$ cell responses to the AFP antigen and $\mathrm{AdV}$ vector were tested by direct IFN $\gamma$ ELISPOT at every time point, and assays were batched to reduce assay variability. $\mathrm{HD}$ did not have detectable IFN $\gamma$-producing AFP-specific T cells, and 2 of 3 of HD had detectable AdV-specific T cells ( $>10$ spots $/ 10^{5}$ cells) (Additional file 1 : Figure S1). Patient 7 had AFP-specific $\mathrm{CD}^{+} \mathrm{T}$ cells at baseline, but no AFP-specific $\mathrm{CD}^{+} \mathrm{T}$ cells (Figure 1A). The AFP-specific $\mathrm{CD}^{+} \mathrm{T}$ cell frequency fluctuated through the vaccination period, and declined during follow up (d168) but did not increase with vaccination. A low frequency of AFP-specific $\mathrm{CD}^{+} \mathrm{T}$ cells were only detected at d168. A very low frequency response to the HLA-A2-restricted $\mathrm{AFP}_{325}$ peptide was detected after the 

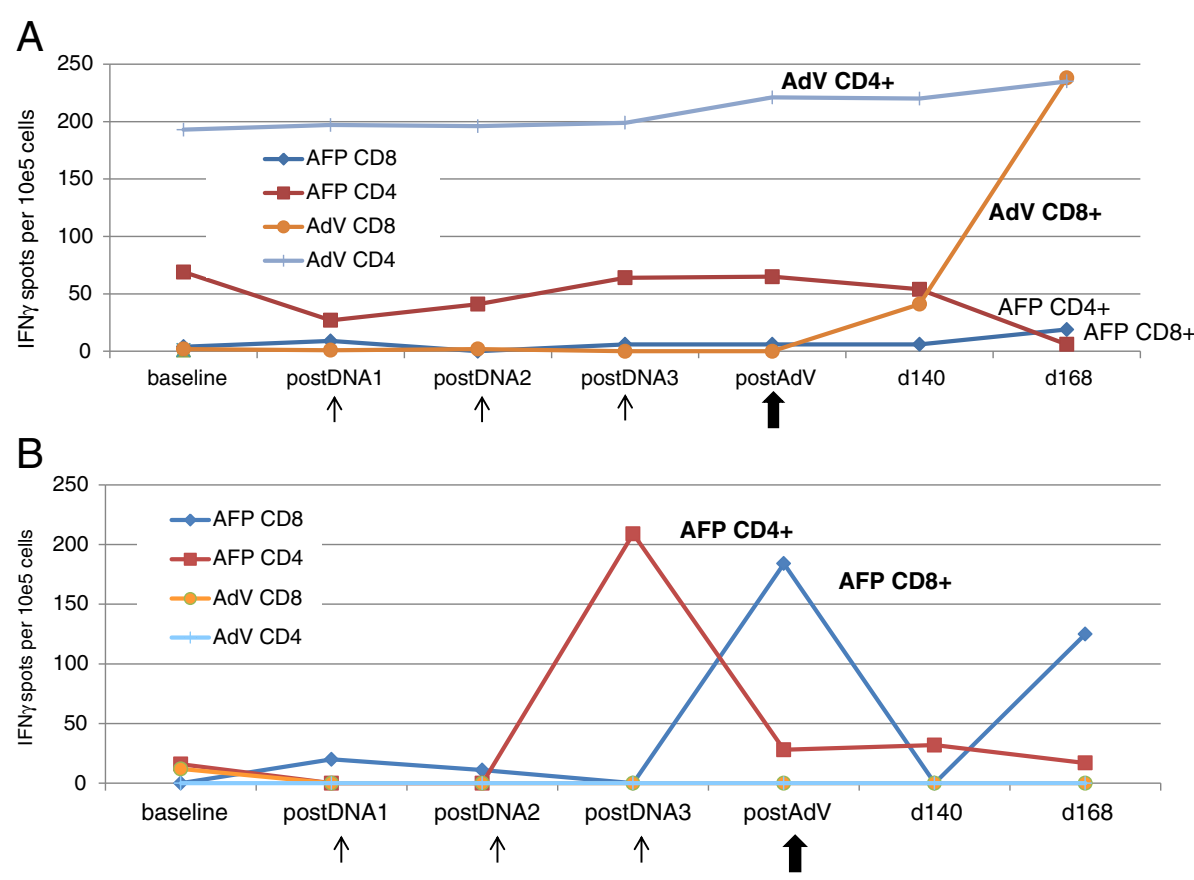

Figure $1 \mathrm{IFN}$ ELISPOT assay testing $\mathrm{CD}^{+}$and $\mathrm{CD}^{+}{ }^{+} \mathrm{T}$ cell responses to AFP and AdV. Patient PBMC from all time points were thawed and batch tested by direct IFNY ELISPOT for recognition of autologous DC alone (background), DC transduced with AdVLacZ (for AdV responses) or co-cultured with AFP protein. Responses were also tested to HLA-A2 restricted peptides pulsed onto T2 cells (not shown). The spot counts after background ( $T$ cells $+D C$ alone) per $10^{5} \mathrm{~T}$ cells is shown. A: Patient 7 responses are shown. Thin arrows indicate blood draws one month after each plasmid DNA injection and the thick arrow shows the blood draw one month after the AdV boostb. B: Patient 8 responses are shown as in $1 \mathrm{~A}$.

first and third pAFP injections, and responses to other characterized AFP epitopes were not detected (not shown). Overall, the AFP-specific immune response to vaccination was very weak in patient 7 .

Patient 7 also had detectable baseline $\mathrm{CD} 4^{+} \mathrm{T}$ cells specific to AdV, at almost $2 / 10^{3} \mathrm{~T}$ cell frequency. These levels were maintained through the plasmid DNA injections, but increased after the AdV boost. A strong induction of AdV-specific $\mathrm{CD} 8^{+} \mathrm{T}$ cells was detected at $\mathrm{d} 140$ and $\mathrm{d} 168$. These data indicate that the intramuscularly-delivered (i.m.) AdVhAFP was immunogenic and capable of broadly activating a polyclonal $\mathrm{T}$ cell response to $\mathrm{AdV}$ antigens.

Patient 8 had a very different cellular response to the vaccination regimen (Figure 1B). Her AFP-specific CD8 ${ }^{+}$ and $\mathrm{CD}^{+} \mathrm{T}$ cell response predominated, and her minimal baseline AdV-specific response decreased and was not increased with the AdVhAFP boost. Her AFPspecific $\mathrm{CD}^{+} \mathrm{T}$ cell response was low at baseline, but strongly increased after the third pAFP injection, and remained above baseline through $\mathrm{d} 168$. The AFPspecific $\mathrm{CD}^{+} \mathrm{T}$ cells were minimally induced by the first two pAFP injections, but highly positive after the AdVhAFP boost, and still high at d168. Responses to individual HLA-A2-restricted AFP peptides were not detected (data not shown). These data demonstrate that the prime-boost regimen could induce high frequencies of circulating AFP-specific T cells, even with a relatively low dose of $10^{9}$ AdVhAFP viral particles.

These different cellular responses may have been impacted by the levels of circulating anti-AdV neutralizing antibodies in each patient, which might influence the ability to respond to the i.m. injected AdVhAFP boost. Therefore, we examined both anti-AdV neutralizing antibodies and total AdV-specific antibodies in each patient.

\section{Humoral immune responses to AdV were detected}

Patients were initially screened for trial eligibility to exclude those with very high levels of circulating anti-AdV neutralizing antibodies. Ten HD were tested to standardize the assay, and to identify the range of antibodies likely to be detected (Additional file 2: Figure S2). Most donors had detectable antibodies, 1 of 10 had high levels (pink squares).

Interestingly, patient 7 did not have detectable anti-AdV neutralizing antibodies (Figure 2A), and there was no induction of an antibody response after AdVhAFP injection. In contrast, patient 8 did have a detectable level of neutralizing antibodies (Figure 2B). The level was stable through pAFP injections, was boosted after the AdVhAFP 

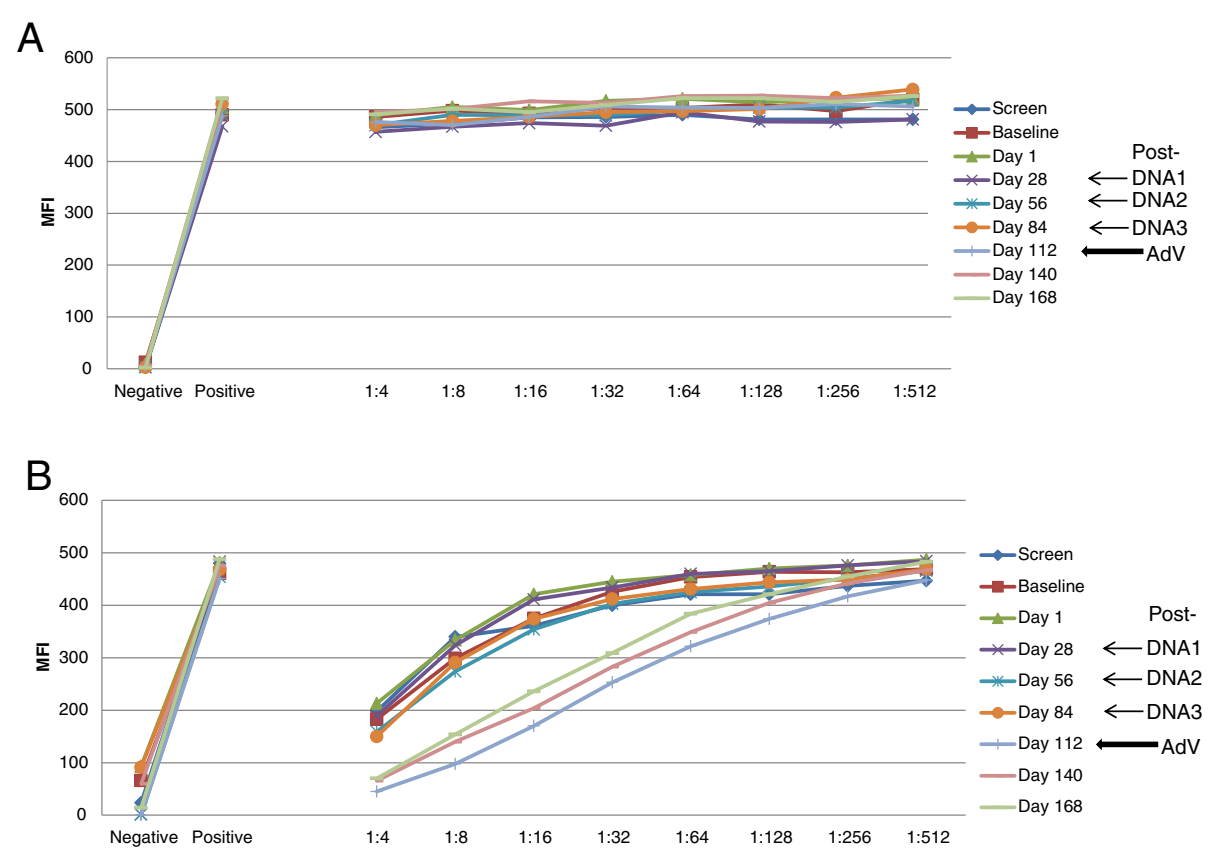

Figure 2 Serum anti-AdV neutralizing antibodies. The MFI of AdVeGFP-transduced A549 cells incubated with dilutions of serum is shown, with positive and negative assay controls. A: Results from patient 7 show no evidence of anti-AdV neutralizing antibody induction. Baseline levels show no inhibition of AdVeGFP transduction of A549 cells. B: Results from patient 8 show that the AdV boost induced increased titers of anti-AdV neutralizing antibodies. Patient 8 shows positive baseline neutralizing antibodies as well.

injection, and then stably higher through d168. These data suggest that the lack of anti-AdV neutralizing antibodies in patient 7 does not explain the limited activation of AFP-specific T cells, and that a higher level of anti-AdV neutralizing antibodies in no way inhibited development of an AFP-specific cellular response in patient 8 .

Total AdV-specific antibodies were also tested by ELISA. Patients 7 and 8 had levels that were in a similar range with other screened HCC patients and HD (Figure 3). Patient 7 had lower levels and patient 8 had higher levels (similar to their relative neutralizing antibody levels, Figure 2). These total AdV antibodies were not detectably modulated by i.m. AdVhAFP injection.

\section{Circulating treg, MDSC and lymphocyte subsets}

Fresh flow cytometry was performed at each time point to detect changes in activated $\mathrm{T}$ cells and NK cells, as well as frequencies of suppressive cells MDSC and Treg. We hypothesized that high baseline levels of Treg or MDSC might inhibit antigen-specific immune responses,

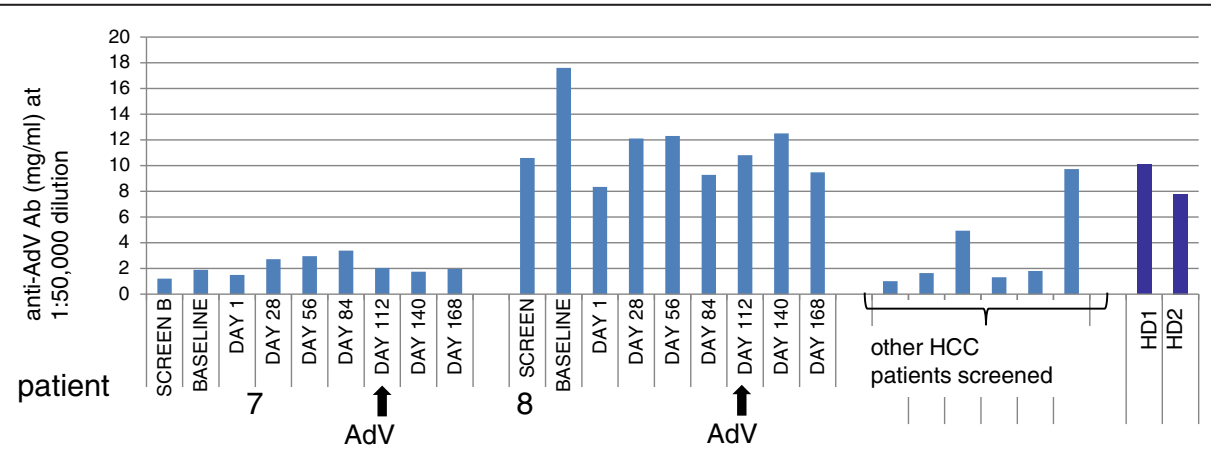

Figure 3 Total anti-adenovirus antibodies. The total AdV ELISA results show no increase in total anti-AdV antibodies associated with AdvhAFP vaccination for either patient $(7,8)$. Also shown are HD controls (HD1, HD2) and serum from other HCC patients screened for the trial. 
and that the vaccine might activate a detectable percentage of circulating $\mathrm{T}$ or NK cells. Differences in several cellular subsets were detected, however it is impossible to draw firm conclusions from the two different patients (Additional file 3: Figure S3). Of note, patient 8 did have a lower frequency of monocytic $\mathrm{CD} 11 \mathrm{~b}^{+} / \mathrm{CD}_{3} 3^{+}$ MDSC, and higher frequencies of activated NK cells $\left(\mathrm{CD} 6^{+} / \mathrm{CD}^{\circ} 9^{+}\right)$, which could be examined in future trials to determine whether these subsets are potential immune biomarkers.

\section{Serum cytokines, chemokines and growth factors}

Patient sera was tested for a variety of cytokines, chemokines and growth factors by Multiplex Luminex to identify serum biomarkers of response (Figure 4). Patient 8 had higher levels of G-CSF and CXCL10/IP-10, and lower CXCL8/IL-8, MIP-1 $\beta$, Eotaxin, RANTES, MCP-1, EGF and HGF, relative to patient 7. Patient 8 also had a greater increase in IL-15 than patient 7.

There was no detectable IL-2, IL-5, IL-6, IL-7, IL-13, IL-17, TNF $\alpha$, IFN $\gamma$, GM-CSF or VEGF over background (LLD). IL-1 $\beta$, IL-4, IL-10, MIP- $1 \alpha$ and bFGF were detectable but at very low levels that did not change with vaccination. IL-12p40/p70, IL-1RA and IL-2R were detected at somewhat higher levels, but also showed no change with vaccination. These data serve to suggest specific analytes which may be worthwhile to examine in a larger trial.

\section{Discussion}

In this report, we present data on two previously treated $\mathrm{HCC}$ patients receiving a novel DNA prime-AdV boost vaccine to promote an AFP-specific cellular response. Both patients were at a similar advanced age, and were stage II HCC patients with AFP-positive tumors which were previously treated. There were no treatmentrelated toxicities observed. The dose of AdVhAFP boost that they received, $10^{9}$ particles, was proposed as the low dose cohort level. This dose appeared to serve as a boost for both AFP-specific and AdV-specific T cell responses. It also boosted the level of circulating anti-AdV neutralizing antibodies in one patient. It was not a sufficient dose to promote detectable anti-AdV neutralizing antibodies in the other patient. It is possible that $10^{10}$ or $10^{11}$ AdVhAFP particles would be a stronger boost, better able to promote antitumor immunity (and antiviral antibody responses) than the $10^{9}$ dose.

Importantly, the presence of anti-AdV neutralizing antibodies at baseline, and boosting the antibody level by AdV injection, did not negatively impact AFP-specific $\mathrm{T}$ cell responses, as seen in patient 8 . This finding implies that it might be possible to give additional boosts of AdVhAFP to further increase $\mathrm{T}$ cell responses, because a single injection may not result in detectable neutralizing antibody titers (patient 7), or may result in a neutralizing antibody titer that does not block downstream $\mathrm{T}$ cell activation and expansion.

Both patients were successfully vaccinated, but patient 7 expanded only AdV-specific T cells and recurred earlier with an AFP-positive tumor. Patient 8 expanded AFP-specific $\mathrm{T}$ cells and anti-AdV antibodies, but had minimal AdV-specific $\mathrm{T}$ cells and recurred at a later time, with an AFP-negative tumor. These data suggest that activation of an AFP-specific, type $1 \mathrm{~T}$ cell response may have therapeutic potential and should be examined in a larger trial. The additional immunologic assessments presented also shed light on possible mechanisms of the different outcomes of the patients. Patient 8 had

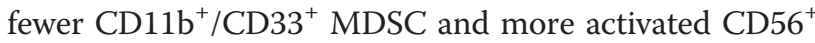
NK cells at baseline, and also had a more favorable type 1 cytokine/chemokine/growth factor milieu in her serum. These observations suggest assessments that should be included in future studies of this vaccine regimen.

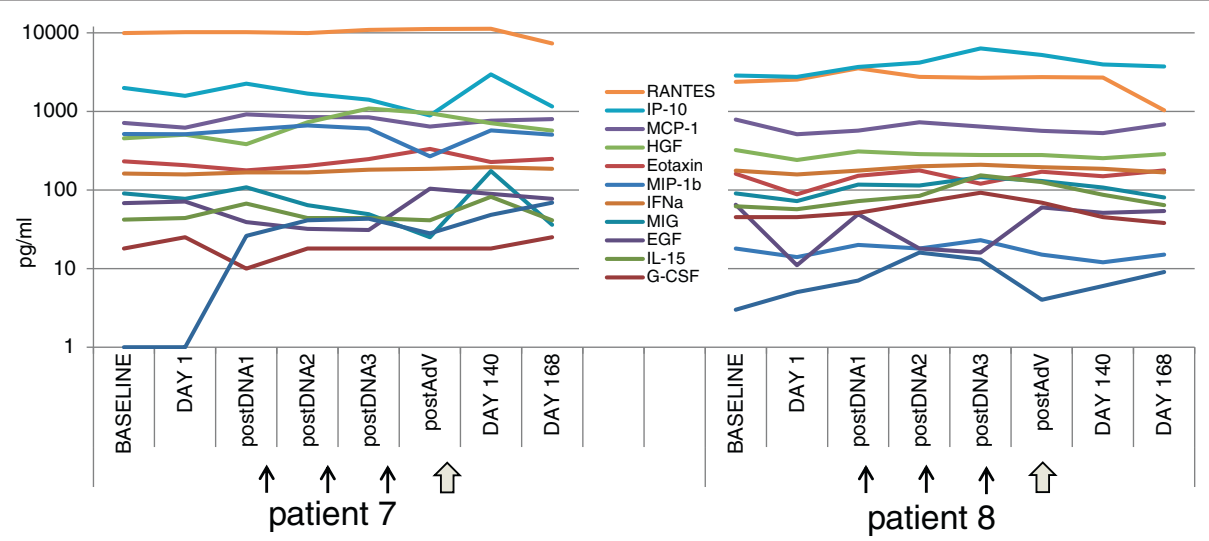

Figure 4 Multiplex serum cytokine, chemokine and growth factor assessment. The levels of a broad array of analytes were tested by Luminex assay in the serum of patients 7 and 8 . The levels of the 12 most highly detected analytes are graphed on a log scale in pg/ml. 


\section{Additional files}

Additional file 1: Figure S1. Healthy Donor Controls: ELISPOT for AFP and AdV-specific T Cells. To standardize the direct IFNY ELISPOT assay for $T$ cell responses to AFP and AdV antigens and AFP-derived peptides, the assays were performed with blood from $3 \mathrm{HD}$. Two of three HD have detectable AdV-specific T cells (to AdVLacZ-transduced DC marked " $A d V^{\prime \prime}$ ), none have spontaneous AFP-specific T cells (by AFP proteinloaded DC or T2 cells pulsed with synthetic HLA-A2-restricted AFPderived peptides).

Additional file 2: Figure S2. AdV Neutralizing Antibody Assay: 9 healthy donors. To standardize the anti-AdV neutralizing antibody assay, sera from 9 HD were tested over serial two-fold dilutions. In "week 1", 3 donors were tested, positive and negative controls and results are shown. The following week, 6 different donors were tested. One of the tested donors had high levels of anti-AdV neutralizing antibodies (pink square). Most differences between $\mathrm{HD}$ are in the 1:4 to 1:32 dilution range.

Additional file 3: Figure S3. Fresh flow cytometry analysis of suppressive cells and lymphocyte subsets is shown. Whole blood was stained as indicated to test for the circulating frequencies of MDSC small, "lymphocyte gate" and larger "monocyte gate" CD11 $\mathrm{b}^{+} \mathrm{CD} 33^{+} \mathrm{MDSC}$ and monocyte gate CD $14^{+}\left(\mathrm{HLA}-\mathrm{DR}{ }^{\text {low }} \mathrm{MDSC}\right)$, Treg $\left(\mathrm{CD}^{+} \mathrm{CD}^{+} \mathrm{CD} 25^{\text {high }} \mathrm{FoxP}^{+}\right)$and lymphocytes (T, NK and NK/T cells). Sufficient blood was not obtained from Patient 8 at later time points for all assays.

\section{Abbreviations}

AFP: Alpha fetoprotein; HCC: Hepatocellular cancer; AdV: Adenovirus; US: United States; PBMC: Peripheral blood mononuclear cells; HBV: Hepatitis B virus; HCV: Hepatitis C virus; RFA: Radiofrequency ablation; TAE: Transarterial embolization; LLD: Lower limit of detection; GMP: Good manufacturing practice; IM: Intramuscular.

\section{Competing interests}

LHB and JSE are co-inventors on issued patents covering aspects of AFP and AFP-derived peptides as a target for T cell mediated anti-HCC immunotherapy. UCLA holds the patents, and they have not been optioned or licensed.

\section{Authors' contributions}

LHB designed the trial, designed and analyzed the immunologic monitoring assays, and wrote the manuscript. JSE designed the trial and wrote the manuscript. TCG made helpful suggestions to the clinical protocol and screened HCC patients. DAG made helpful suggestions to the protocol, screened and enrolled patients and wrote the manuscript. All authors read and approved the final manuscript.

\section{Acknowledgments}

This project was supported by the UPCI Immunologic Monitoring and Cellular Products Laboratory (IMCPL) that is supported in part by award P30CA047904, by National Institutes of Health R01 CA104524 (L.H.B.), and by RAID Project 176 (J.S.E.). We acknowledge and thank Susan Lamson, R.N., for clinical coordination, James Pingpank, MD for support, Richard Finn, M.D. for screening patients at UCLA, and Rose Aurigemma, Ph.D. for her leadership and support during the RAID project development, vaccine manufacturing, and IND submission.

\section{Author details}

'University of Pittsburgh Cancer Institute, Departments of Medicine, Surgery, and Immunology, University of Pittsburgh, 5117 Centre Avenue, PA, Pittsburgh 15213, USA. 'David Geffen School of Medicine at UCLA, Departments of Surgery, Microbiology, Immunology, and Molecular Genetics, Molecular and Medical Pharmacology, Los Angeles, CA, USA. ${ }^{3}$ Medical College of Wisconsin, Department of Surgery, Milwaukee, WI, USA. ${ }^{4}$ University of Pittsburgh School of Medicine, Department of Surgery, Pittsburgh, PA, USA.

Received: 28 March 2014 Accepted: 29 March 2014

Published: 5 April 2014

\section{References}

1. El-Serag HB, Rudolph KL: Hepatocellular carcinoma: epidemiology and molecular carcinogenesis. Gastroenterology 2007, 132:2557-2576.

2. Altekruse SF, McGlynn KA, Reichman ME: Hepatocellular carcinoma incidence, mortality, and survival trends in the United States from 1975 to 2005. J Clin Oncol 2009, 27:1485-1491.

3. Di Bisceglie AM, Lyra AC, Schwartz M, Reddy RK, Martin P, Gores G, Lok AS, Hussain KB, Gish R, Van Thiel DH, Younossi Z, Tong M, Hassanein T, Balart L, Fleckenstein J, Flamm S, Blei A, Befeler AS: Liver Cancer Network: Hepatitis C-related hepatocellular carcinoma in the United States: influence of ethnic status. Am J Gastroenterol 2003, 98:2060-2063.

4. Nordenstedt $\mathrm{H}$, White $\mathrm{DL}$, El-Serag HB: The changing pattern of epidemiology in hepatocellular carcinoma. Dig Liver Dis 2010, 42(Suppl 3):S206-214.

5. El-Serag HB, Marrero JA, Rudolph L, Reddy KR: Diagnosis and treatment of hepatocellular carcinoma. Gastroenterology 2008, 134:1752-1763.

6. Llovet JM, Ricci S, Mazzaferro V, Hilgard P, Gane E, Blanc JF, de Oliveira AC, Santoro A, Raoul JL, Forner A, Schwartz M, Porta C, Zeuzem S, Bolondi L, Greten TF, Galle PR, Seitz JF, Borbath I, Haussinger D, Giannaris T, Shan M, Moscovici M, Voliotis D, Bruix J: SHARP Investigative Study Group: Sorafenib in advanced hepatocellular carcinoma. N Engl J Med 2008 , 359:378-390.

7. Siegel AB, Olsen SK, Magun A, Brown RS Jr: Sorafenib: where do we go from here? Hepatology 2010, 52:360-369.

8. Song R, Ikeguchi M, Zhou G, Kuo MT: Identification and characterization of a hepatoma cell-specific enhancer in the mouse multidrug resistance mdr1b promoter. J Biol Chem 1995, 270:25468-25474.

9. Wada Y, Nakashima O, Kutami R, Yamamoto O, Kojiro M: Clinicopathological study on hepatocellular carcinoma with lymphocytic infiltration. Hepatology 1998, 27:407-414.

10. Mizejewski GJ: Alpha-fetoprotein structure and function: relevance to isoforms, epitopes, and conformational variants. Exp Biol Med 2001, 226:377-408.

11. Mizejewski GJ: Biological role of alpha-fetoprotein in cancer: prospects for anticancer therapy. Expert Rev Anticancer Ther 2002, 2:709-735.

12. Um SH, Mulhall C, Alisa A, Ives AR, Karani J, Williams R, Bertoletti A, Behboudi S: Alpha-fetoprotein impairs APC function and induces their apoptosis. J Immunol 2004, 173:1772-1778.

13. Meng WS, Butterfield LH, Ribas A, Dissette VB, Heller JB, Miranda GA, Glaspy $J A, M c B r i d e ~ W H$, Economou JS: Alpha-Fetoprotein-specific tumor immunity induced by plasmid prime-adenovirus boost genetic vaccination. Cancer Res 2001, 61:8782-8786.

14. Butterfield LH, Ribas A, Meng WS, Dissette VB, Amarnani S, Vu HT, Seja E, Todd K, Glaspy JA, McBride WH, Economou JS: T-cell responses to HLA$A^{*} 0201$ immunodominant peptides derived from alpha-fetoprotein in patients with hepatocellular cancer. Clinical Cancer Res 2003, 9:5902-5908.

15. Butterfield LH, Ribas A, Potter DM, Economou JS: Spontaneous and vaccine induced AFP-specific T cell phenotypes in subjects with AFP-positive hepatocellular cancer. Cancer Immunol Immunother 2007, 56:1931-1943.

16. Evdokimova VN, Liu Y, Potter DM, Butterfield LH: AFP-specific CD4+ helper T-cell responses in healthy donors and HCC patients. J Immunother 2007, 30:425-437.

17. Vollmer CM Jr, Eilber FC, Butterfield LH, Ribas A, Dissette VB, Koh A, Montejo LD, Lee MC, Andrews KJ, McBride WH, Glaspy JA, Economou JS: Alphafetoprotein-specific genetic immunotherapy for hepatocellular carcinoma. Cancer Res 1999, 59:3064-3067.

18. Thimme R, Neagu M, Boettler T, Neumann-Haefelin C, Kersting N, Geissler M, Makowiec F, Obermaier R, Hopt UT, Blum HE, Spangenberg HC: Comprehensive analysis of the alpha-fetoprotein-specific CD8+ T cell responses in patients with hepatocellular carcinoma. Hepatology 2008, 48:1821-1833.

19. Greten TF, Ormandy LA, Fikuart A, Hochst B, Henschen S, Horning M, Manns MP, Korangy F: Low-dose cyclophosphamide treatment impairs regulatory $T$ cells and unmasks AFP-specific CD4+ T-cell responses in patients with advanced HCC. J Immunother 2010, 33:211-218.

20. Yang ZF, Ho DW, Ng MN, Lau CK, Yu WC, Ngai P, Chu PW, Lam CT, Poon RT, Fan ST: Significance of CD90+ cancer stem cells in human liver cancer. Cancer Cell 2008, 13:153-166.

21. Butterfield LH, Ribas A, Dissette VB, Lee Y, Yang JQ, De la Rocha P, Duran SD, Hernandez J, Seja E, Potter DM, McBride WH, Finn R, Glaspy JA, Economou JS: A phase I/II trial testing immunization of hepatocellular carcinoma patients with dendritic cells pulsed with four alphafetoprotein peptides. Clin Cancer Res 2006, 12:2817-2825. 
22. Bos $R$, Sherman $L A: C D 4+T$-cell help in the tumor milieu is required for recruitment and cytolytic function of CD8+ T lymphocytes. Cancer Res 2010, 70:8368-8377.

23. Wong SB, Bos R, Sherman LA: Tumor-specific CD4+ T cells render the tumor environment permissive for infiltration by low-avidity CD8+ T cells. J Immunol 2008, 180:3122-3131.

24. Kantoff PW, Schuetz TJ, Blumenstein BA, Glode LM, Bilhartz DL, Wyand M, Manson K, Panicali DL, Laus R, Schlom J, Dahut WL, Arlen PM, Gulley JL, Godfrey WR: Overall survival analysis of a phase II randomized controlled trial of a Poxviral-based PSA-targeted immunotherapy in metastatic castration-resistant prostate cancer. J Clin Oncol 2010, 28:1099-1105.

25. Butterfield LH, Koh A, Meng W, Vollmer CM, Ribas A, Dissette V, Lee E, Glaspy JA, McBride WH, Economou JS: Generation of human T-cell responses to an HLA-A2.1-restricted peptide epitope derived from alpha-fetoprotein. Cancer Res 1999, 59:3134-3142.

26. Nwanegbo E, Vardas E, Gao W, Whittle H, Sun H, Rowe D, Robbins PD, Gambotto A: Prevalence of neutralizing antibodies to adenoviral serotypes 5 and 35 in the adult populations of the Gambia, South Africa, and the United States. Clin Diagn Lab Immunol 2004, 11:351-357.

doi:10.1186/1479-5876-12-86

Cite this article as: Butterfield et al: Alpha fetoprotein DNA prime and adenovirus boost immunization of two hepatocellular cancer patients. Journal of Translational Medicine 2014 12:86.

\section{Submit your next manuscript to BioMed Central and take full advantage of:}

- Convenient online submission

- Thorough peer review

- No space constraints or color figure charges

- Immediate publication on acceptance

- Inclusion in PubMed, CAS, Scopus and Google Scholar

- Research which is freely available for redistribution 